\title{
Revisiting the first long-term culture of antigen-specific cytotoxic T cells
}

\author{
Kendall A. Smith* \\ The Division of Immunology, Department of Medicine, Weill Medical College, Cornell University, New York, NY, USA \\ ${ }^{*}$ Correspondence: kasmith@med.cornell.edu \\ Edited by: \\ Michael Loran Dustin, Oxford University, UK \\ Reviewed by: \\ Ellis L. Reinherz, Dana-Farber Cancer Institute, USA \\ Michael Loran Dustin, Oxford University, UK
}

Keywords: cytotoxic T-lymphocytes, lymphocyte-conditioned media

Prior to the publication of this article [link to Ref. (1)], immunological dogma held that lymphocyte proliferation was only initiated and sustained by antigenic (or mitogenic) stimulation. In support of this notion, several investigators had reported that repetitive stimulation of $\mathrm{T}$ cells with allogeneic lymphocytes in a mixed lymphocyte culture could result in the longterm culture of alloreactive $\mathrm{T}$ cells for several months (2-5). With the re-addition of irradiated allogeneic stimulator cells, usually every 2 weeks, a burst of proliferation would ensue, followed by a gradual tapering of the proliferative rate of the cell population until a subsequent re-stimulation. The cellular response was assumed to be entirely antigen-driven, such that as the irradiated allogeneic stimulator cells gradually died out, the responder cells naturally defaulted to a quiescent state, since there was no longer an antigenic drive.

However, even before these reports, a decade of publications, the first in 1965, indicated that the allogeneic or mitogenic stimulation of $\mathrm{T}$ cells "conditioned" the media, presumably by activating the cells to release soluble mitogenic "factor activities" for $\mathrm{T}$ cells (6-13). At the time, the molecules responsible for the putative activities remained totally obscure, in that the available analytical and preparative biochemical methods were fairly rudimentary.

In addition to T-cell mitogenic activities, Martin Cline and David Golde had reported that human lymphocytes stimulated with phytohemagglutinin (PHA)conditioned media that would promote the formation of granulocyte and monocyte colonies in soft agar (14). Then, Doris Morgan, a hematopoietic biologist who had been searching for a factor activity that might sustain long-term leukemia cell proliferation, reported that PHA-stimulated human lymphocyte-conditioned media promoted not leukemia cell growth, but long-term T-cell proliferation (15). It was somewhat of a surprise that mitogenic activities from lymphocyte-conditioned media could select for and support the continuous culture of human $\mathrm{T}$ cells for as long as 13 weeks. However, as the cellular source was bone marrow, it was assumed by many that the $\mathrm{T}$ cells might be immature precursors, and not mature antigen-reactive $\mathrm{T}$ cells.

At the time, we were in the process of examining ways to promote the generation of cytotoxic T-lymphocytes (CTL) capable of lysing murine leukemia cells. Working under the hypothesis that allogeneic leukemia cells might promote an enhanced generation of CTL lytic not only for allogeneic but also syngeneic leukemias, we had already found that secondary and tertiary allogeneic mixed tumor-lymphocyte cultures markedly augmented the lytic efficiency of CTLs, especially against syngeneic leukemia cells (16). Even so, we had not tried to culture our CTLs beyond several days, assuming that they would progressively die out. However, given Morgan's report, we hoped that after an initial antigenic stimulation we might use lymphocyte-conditioned media to sustain long-term CTL proliferation with maintenance of lytic activity. Because concanavalin-A (Con-A) is a more potent mitogen for murine vs. human $T$ cells, we produced Con-A T-cell supernatants, which one immunologist derisively abbreviated CATSUP, and seeded cell populations with CTL activity into 50\% CATSUP. After several failed attempts by everyone in the lab, Steven Gillis, a graduate student and neophyte in cell culture, found that cells could be maintained in long-term culture provided they were seeded at low cell densities, $\sim 5 \times 10^{3}$ cells $/ \mathrm{mL}$, and never allowed to surpass $\sim 5 \times 10^{5}$ cells $/ \mathrm{mL}$ (1). We speculated that perhaps low cell densities were necessary because the growth factor(s) in the CATSUP became limiting. Perhaps the high cell densities somehow consumed the activities.

The CTL lines (CTLL) retained their lytic activity upon repeated testing, and even increased their lytic efficiency up to 10 -fold over several weeks of culture. Moreover, the CTLL expressed $\theta$ antigens as expected for murine $\mathrm{T}$ cells, and tested negative for various histochemical stains specific for myeloid cells. WrightGiemsa staining revealed lymphoblasts and highly vacuolated cytoplasm. Other tests at the time revealed electron-dense granules, which were subsequently found to be the cytolytic granules containing perforin and granzymes, the molecules responsible for T-cell cytolysis.

These findings were provocative for several reasons. First, the data were against the dogma that only antigens were responsible for T-cell proliferation. The data were also contrary to the notion that differentiated T-cell lytic activity and proliferation were mutually exclusive, as well as against the Hayflick hypothesis that normal cells, as opposed to malignant cells, were limited to $\sim 50$ cellular divisions before senescence ensued (17). Moreover, because the CTLL were capable of lysis of syngeneic leukemia cells, we speculated that it might be possible 
to generate human CTLL via allogeneic mixed tumor-lymphocyte cultures, which then could be expanded in vitro with CATSUP and used as adoptive immunotherapy to actually treat human leukemia.

Accordingly, we proudly submitted our manuscript to Nature. We felt that this paper was worthy of such a prestigious journal as Nature because we had shown that it is possible to culture antigenspecific functional cytolytic T cells apparently indefinitely without antigen, which was totally against the dogma that antigen was solely responsible for lymphocyte proliferation. Also, we had succeeded in selecting and culturing not only antigenspecific CTL, but also tumor antigenspecific CTLL, a holy grail of tumor immunology. However, almost by return post we received our manuscript back un-reviewed and rejected. The terse form letter from the editor said that because Nature received so many excellent manuscripts they could not possibly review all of them. I personally was so incensed that I immediately fired off a letter to the editor, explaining why this particular manuscript should be reviewed "by someone with more than a cursory education in immunology." The good part of this story is that they reviewed and accepted our manuscript without changes, and it appeared on Bastille day in 1977.

This article eventually led to the generation of the first cytolytic T-cell clones, which will be the subject of another article in the series of "living immunological history" (18). However, we knew that we had difficult work ahead of us, in that our CATSUP, which was essential for our successful culture of CTLL, contained both a mitogenic lectin as well as any putative molecule(s) with soluble mitogenic activity. Which of the two was actually responsible for initiating and sustaining long-term T-cell growth had to be left to the future.

\section{ACKNOWLEDGMENTS}

The author thanks the Belfer Foundation for continued support.

\section{REFERENCES}

1. Gillis S, Smith KA. Long term culture of tumour-specific cytotoxic T cells. Nature (1977) 268(5616):154-6. doi:10.1038/268154a0

2. McDonald H, Engers H, Cerottini J, Bruner BT. Generation of cytotoxic $\mathrm{T}$ lymphocytes in vitro. II. The effect of repeated exposure to alloantigens on the cytotoxic activity of long-term mixed leukocyte cultures. J Exp Med (1974) 140:718-30. doi:10.1084/jem.140.3.718

3. Svedmyr E. Long-term maintenance in vitro of human $\mathrm{T}$ cells by repeated exposure to the same stimulator cells. Scand J Immunol (1975) 4:421-7. doi:10.1111/j.1365-3083.1975.tb02647.x

4. Ben-Sasson S, Paul W, Shevach E, Green I. In vitro selection and extended culture of antigen-specific T lymphocytes. I. Description of selection procedure and initial characterization of selected cells. J Exp Med (1975) 142:90-105. doi:10.1084/jem. 142.1 .90

5. Dennert G, De Rose M. Continuously proliferating $\mathrm{T}$ killer cells specific for $\mathrm{H}-2 \mathrm{~b}$ targets: selection and characterization. J Immunol (1976) 116(6):1601-6.

6. Kasakura S, Lowenstein L. A factor stimulating DNA synthesis derived from the medium of leukocyte cultures. Nature (1965) 208:794-5. doi:10. $1038 / 208794 \mathrm{a} 0$

7. Gordon J, MacLean LD. A lymphocyte-stimulating factor produced in vitro. Nature (1965) 208:795-6. doi:10.1038/208795a0

8. Bach F, Alter B, Solliday S, Zoschke D, Janis M. Lymphocyte reactivity in vitro II. Soluble reconstituting factor permitting response of purified lymphocytes. Cell Immunol (1970) 1:219-27. doi:10. 1016/0008-8749(70)90009-2

9. Dutton RW, McCarthy MM, Mishell RI, Raidt DJ. Cell components in the immune response. IV. Relationships and possible interactions. Cell Immunol (1970) 1:196-206. doi:10.1016/00088749(70)90007-9

10. Hoffman M, Dutton R. Immune response restoration with macrophage culture supernatants.
Science (1971) 172:1047-8. doi:10.1126/science. 172.3987 .1047

11. Gery I, Gershon RK, Waksman B. Potentiation of the T-lymphocyte response to mitogens I. The responding cell. J Exp Med (1972) 136:128-42. doi:10.1084/jem.136.1.143

12. Gery I, Waksman BH. Potentiation of the Tlymphocyte response to mitogens: the cellular source of potentiating mediators. J Exp Med (1972) 136:143-55. doi:10.1084/jem.136.1.143

13. Schimpl A, Wecker E. Replacement of T cell function by a T cell product. Nat New Biol (1972) 237:15-7. doi:10.1038/newbio237015a0

14. Cline M, Golde D. Production of colonystimulating activity by human lymphocytes. Nature (1974) 248:703-4. doi:10.1038/248703a0

15. Morgan DA, Ruscetti FW, Gallo R. Selective in vitro growth of $\mathrm{T}$ lymphocytes from normal human bone marrows. Science (1976) 193(4257):1007-8. doi:10.1126/science. 181845

16. Gillis S, Smith K. In vitro generation of tumorspecific cytotoxic lymphocytes. Secondary allogeneic mixed tumor lymphocyte culture of normal murine spleen cells. J Exp Med (1977) 146:468-82. doi:10.1084/jem.146.2.468

17. Hayflick L, Moorhead P. The serial cultivation of human diploid cell strains. Exp Cell Res (1961) 25:585-621. doi:10.1016/0014-4827(61)90192-6

18. Baker PE, Gillis S, Smith KA. Monoclonal cytolytic T-cell lines. J Exp Med (1979) 149(1):273-8. doi: 10.1084/jem.149.1.273

Conflict of Interest Statement: The author declares that the research was conducted in the absence of any commercial or financial relationships that could be construed as a potential conflict of interest.

Received: 16 March 2014; accepted: 19 April 2014; published online: 05 May 2014.

Citation: Smith KA (2014) Revisiting the first longterm culture of antigen-specific cytotoxic T cells. Front. Immunol. 5:194. doi: 10.3389/fimmu.2014.00194

This article was submitted to T Cell Biology, a section of the journal Frontiers in Immunology.

Copyright (c) 2014 Smith. This is an open-access article distributed under the terms of the Creative Commons Attribution License (CC BY). The use, distribution or reproduction in other forums is permitted, provided the original author(s) or licensor are credited and that the original publication in this journal is cited, in accordance with accepted academic practice. No use, distribution or reproduction is permitted which does not comply with these terms. 